\title{
TOXICITY OF SOME INSECTICIDES AND THEIR MIXTURES WITH ERGISTROL BIOSYNTHESIS INHIBITING FUNGICIDES AGAINST THE $2^{\text {ND }}$ INSTAR LARVAE OF SPODOPTERA LITTORALIS (BOISD)
}

\author{
HASAN F.M. ABDEL- HAMID \\ Plant Protection Research Institute, ARC, Dokki Cairo \\ (Manuscript received 11 June 2014)
}

\begin{abstract}
The toxicity of organophosphorus insecticide (profenofos), pyrethroid insecticide (esfenvalirate), insect growth regulators, (flufenoxuron) and biocide as natural products (spinosad) increased when mixed with the butylated hydroxyanisol (BHA) and ergosterol biosynthesis inhibiting (EBI) fungicides to $2^{\text {nd }}$ instar larvae of Spodoptera littoralis. Present study was carried out by feeding $2^{\text {nd }}$ instar larvae on castor bean leaves treated with different concentrations of profenofos, esfenvalirate, flufenoxuron and spinosad either alone or in mixtures with BHA, EBI fungicide or IGR. Interestingly, these BHA and EBI did not kill the larvae at concentration up to $100 \mathrm{ppm}$, moreover $20 \mathrm{ppm}$ of each BHA or EBI fungicide with concentrations of the insecticides increased the toxicity of these insecticides. Also, all data indicated that the calculated $\mathrm{LC}_{50}$ of the insecticides alone were higher than the insecticides and BHA, EBI fungicides or IGR. For instance, the $\mathrm{LC}_{50}$ of profenofos alone was $1.90 \mathrm{ppm}$, decreased to $0.08,0.20,0.24$ and $0.22 \mathrm{ppm}$ when mixed with $\mathrm{BHA}$, difenoconazol, penconazol and flufenoxuron respectivily. Also, the insecticidal action increased by $23.75,9.5,7.91$ and 8.63 folds. The $L C_{50}$ values decreased when esfenvalirate mixed with BHA, difenoconazol, penconazol and flufenoxuron reached $0.32,0.21,0.28$ and $0.33 \mathrm{ppm}$ compared with $1.58 \mathrm{ppm}$ when esfenvalirate used alone. Also, the insecticidal action increased by $4.93,7.52,5.64$ and 4.78 folds when mixed with the mentioned BHA, EBI fungicides or the IGR respectively. Concerning flufenoxuron $\mathrm{LC}_{50}$ values alone was 1.83 decreased to $0.12,0.19$ and $0.22 \mathrm{ppm}$ when mixed with BHA, difenoconazol, penconazol and flufenoxuron respectively, insecticidal action increased by $15.25,9.63$ and 8.31 folds respectively. $\mathrm{LC}_{50}$ values of spinosad was $1.44 \mathrm{ppm}$ when used alone, decreased to $0.21,0.21,0.25$ and $0.20 \mathrm{ppm}$ when was mixed with BHA, difenoconazol, penconazol and flufenoxuron respectively, insecticidal action was increased by $6.85,6.85,5.76$ and 7.2 folds respectively. These results suggested that the antioxidant butylated hydroxyanisol (BHA), ergosterol biosynthesis inhibiting (EBI) fungicides and the IGRs enhanced the insecticidal activity of profenofos, esfenvalirate and spinosad against $2^{\text {nd }}$ instar S. littoralis.
\end{abstract}




\section{INTRODUCTION}

Cotton growers in Egypt have severe economic losses from cotton pests due to reduced yield, low lint quality and increased costs of insecticides (Amin and Gergis 2006). Insect- pests are considered the important factors that influence cotton production and cause damage to the cotton yield. Cotton leaf worm Spodoptera littoralis (Boisd) and the other insect's are the most serious cotton pests in Egypt (Hussein et al. 2002). They caused annually the greatest yield losses from the cultivated area. (Haque1991,.El-Naggar1998). Ergosterol biosynthesis inhibiting EBI fungicides is widely used in controlling pathogenic fungus. This group of fungicides inhibits fungi by blocking the cytochrome P-450 dependent demethylation at the $\mathrm{C}-14$ position and thus inhibiting biosynthesis of the principal fungal sterol ergosterol (Ragsdal and Sislar 1991). This group of fungicides has been identified as potent synergists of pyrethroid insecticides in the honey bee. (Colin and Belzunces 1992). For example, 9-16 folds enhanced toxicity was recorded for the pyrethroid insecticides lambadacyalothrin when combined with the EBI fungicides prochloraz and propiconazol respectively, (Pilling and Jepson 1994). The mechanism of this synergism has been studied by (Plling et al.1995) reported that prochloraz delayed the metabolism, detoxication, excretion of lambadacyalothrin by inhibiting microsomal oxidation, effectively enhancing the toxicity of pyrethroids to the honey bee. Schmuck et al. (2003) found that slight synergistic effect of the thiacloprid to cyprodinil fungicide was observed with honey bee while a significant enhancement was found with EBI fungicides prochloraz and tebuconazol. The insect growth regulator is acting as chitin synthesis inhibitor in insects which confers a remarkable specification with low toxicity to mammals, birds and fish (Flint and Smith 1977). Also, the mixtures between these compounds and traditional insecticides increase the efficiency of these insecticides (Abdel-Sattar and EL-Guindy1988). Also, Raslan (2003) found that all mixtures of $25 \mathrm{ml}$ Spinosad with Consult, Atabron and Dursban at their half- recommended rates per feddan resulted in increasing their activity against the $3^{\text {rd }}$ instars larvae of cotton leaf worm S. littoralis. Also, Helalia et al (2006) found that the toxicity of the biocides was greatly enhanced when used at low rates of conventional insecticides such as pyrethroids and some organophosphorus compounds in combination with $B$. thuringiensis proved to be suitable to control the cotton leafworm Spodoptera littoralis. Abd-EL-Mageed et al (2006), reported that spinosad gave moderately initial and residual effect when tested alone whereas the most pronounced initial effect was achieved when 
spinosad was mixed with methoxyfenozide. Also, they reported that the highest residual activity was noticed when spinosad was mixed with chlorpyrifos. Arakawa Toru (2008) found that Polyoxin AL a fungicide that inhibits chitin synthesis, showed a synergistic effect with benzoylphenylurea insect growth regulators in killing Spodoptera litura larvae. The antioxidant butylated hydroxyanisol which is a food grade chemical, enhanced the activety of fungicides thiabendazol and imazalil against Colletotrichum musae, the caused fungal pathogen of banana anthracnose (Kan et al., 2001) Additionally Mahmoud and Khalifa (2005) found that BHA increased the herbicide activity of the herbicide bensulfuron-methyl against radish especially with low concentration of the herbicides.

Based on these studies, the present work was conducted to evaluate the synergistic action among the antioxidant butylated hydroxyanisol, ergosterol biosynthesis inhibiting fungicides and the IGRs and both organophosphorus, pyrethroids insecticides and one natural product spinosad against the 2nd instar S.littoralis.

\section{MATERIALS AND METHODS}

\section{1-INSECTS: -}

Laboratory strain obtained as egg-masses from Cotton leaf worm Department, Plant Protection Institute, Agric. Res. Center., Giza. and reared as described by El-Dafrawy et al. (1964) under laboratory condition at $25 \pm 2^{\circ} \mathrm{C}$ and $65 \pm 5 \%$ relative humidity. Eggs masses were kept separately in $400 \mathrm{ml}$ glass jar covered with muslin. The jars were provided with castor bean leaves for larval feeding until pupation. The resulting pupae were placed inside each jar, the emerged moths were supplied with a piece of cotton moistened with $10 \%$ sugar solution and Nerium oleander branches were placed in jars for eggs deposition. The deposited egg-masses were collected daily and were left till hatching. The newly hatched larvae were transferred to fresh castor bean leaves and the instar was differentiated. The newly moulted 2 nd instar larvae of $S$. littoralis were used in these studies.

\section{2-CHEMICALS:}

The following insecticides, fungicides were employed:-.

\section{1-INSECTICIDES:}

1-1- Selecron (profenofos 72 \% E.C

1-2 -Sumiat (esvenvalirate $5 \% \mathrm{E} . \mathrm{C}$ )

1-3-Cascade (flufenoxuron $10 \%$ E.C)

1-4-Spintor (Spinosad 24 \% E.C) 


\section{2 -FUNGICIDES}

2- 1- Score (difenoconazol, $25 \%$ E.C)

2 - 2 - Topaz (penconazole, $20 \%$ E. C)

2 -3 -BHA (butylated-hydroxyanisol $100 \% \mathrm{w} / \mathrm{w}$ )

\section{3-TOXICITY TESTS:}

To determine $L_{50}$ values for each tested compounds used alone or in mixtures with EBI fungicides or insect growth regulators, seven concentrations from each compound were prepared by diluting the formulation product with distilled water 6.5, 3.25, 1.62, 0.81, 0.40, 0.20 and $0.10 \mathrm{ppm}$ for profenofos, and 5, 2.5, 1.25, $0.62,0.312,0.156$ and $0.078 \mathrm{ppm}$ for esvenvalirate, $5,2.5,1.25,0.62,0.312$, 0.156 , and $0.078 \mathrm{ppm}$ for flufenoxuron, and $7.5,3.75,1.87,0.93,0.46,0.23$, and $0.11 \mathrm{ppm}$ for spinosad. These concentrations were used alone or in mixtures with $20 \mathrm{ppm}$ of EBI fungicides, BHA or $2 \mathrm{ppm}$ of insect growth regulators. Castor bean leaves were dipped for 15 second in each concentration, then left to dry at room temperature and offered to the newly moulted $2^{\text {nd }}$ instar larvae of $S$. littoralis. Three replicates were carried out for each concentration, ten larvae for replicate placed inside each jar, three treated leaves of each concentration were transferred to these glasses. Treated larvae were allowed to feed on the treated leaves for $24 \mathrm{hr}$, in case of both insecticides and their mixtures with EBI fungicides, BHA but in case insect growth regulators, larvae were fed for $72 \mathrm{hr}$, then in all cases of feeding periods the larvae were transferred to untreated leaves until pupation. On the other hand, three replicates were dipped in distilled water for the same periods as a check treatment.

Corrected mortality percent was obtained using check treatments and Abbott formula (1925). The corrected percentage of mortality of each compound was staticallycalculated according to Finney (1952) to determine the $\mathrm{LC}_{50}$. Synergistic effects were calculated according to Sun and Johnson (1960)) as follows

Synergistic ratio $=\underline{L_{C_{50}}}$ of insecticides only.

$L C_{50}$ of insecticides in mixtures

\section{RESULTS AND DISCUSSION}

1-Toxicity of chemical, natural insecticides and their mixtures on the second instar larvae of Spodoptera littoralis (Boisd)

Results in Table (1) indicate that mortality percentage increased with increasing the concentration of tested compounds. For profenofos mortality 
percentages of the $2^{\text {nd }}$ instar larvae were $20.0,26.66,36.66,40.0,43.33,46.66$ and $73.33 \%$ at $0.10,20,0.40,81,1.62,3.25$ and 6.5 ppm, respectively. Mixing different concentrations of profenofos with BHA resulted in mortality percentages 46.66, 73.33, 83.33, 86.66, 90.0, 96.66 and $100 \%$ at the same tested concentrations of profenofos mixed with BHA, respectively. Profenfos mixed with flufenxuron, difenoconazol and penconazol revealed mortality percentages' ranged between $44.82-100,46.66-100,43.33-100 \%$ for profenofos mixtures with flufenxuron, difenoconazol and penconazol respectively. Regarding S-fenvalirate, at $5 \mathrm{ppm}$, mortality was $75.8 \%$, while it was $100 \%$ after mixing S-fenvalirate with compounds. At 1.25 and $2.5 \mathrm{ppm}$ of S-fenvalirate, mortality percentage of $2^{\text {nd }}$ instar larvae of $S$. littoralis ranged between79.31 and $96.55 \%$ in the different mixtures of S-fenvalirate compared to 44.82 and $48.27 \%$ at concentration 1.25 and $2.5 \mathrm{ppm}$ a S-fenvalirate As for flufenoxuron, at 1.25 and $2.5 \mathrm{ppm}$ it gave mortality less than $50 \%$. That is normal case with IGR compounds, where they revealed low toxicity but they cause highly disruption in the insect biology. Thus, mixing with BHA, difenoconazol, and penconazol revealed synergistic action of flufenoxuron. Cumulative mortality \% of flufenoxuron + BHA ranged from 40 to $100 \%$ while it ranged from 26.66 to $100 \%$ and $24.13-100 \%$ for flufenoxuron + difenoconazol and flufenoxuron + penconazol, respectively. Taking into account spinosad, data in Table (1) indicate that spinosad concentration up to $3.73 \mathrm{ppm}$ represented mortality \% less than $50 \%$, while revealed $73.33 \%$ at $7.5 \mathrm{ppm}$. Concerning spinosad, BHA, EBI fungicide and IGR mixtures shown in the same table clearly indicate that the spinosad toxicity to larvae was increased by adding the BHA, EBI fungicide or IGR to spinosad concentrations. For instance $0.11 \mathrm{ppm}$ of Spinosad caused $13.33 \%$ larval mortality, but the same concentration when mixed with BHA, EBI fungicides, difenoconazol, penconazol or IGR flufenoxuron, caused $36.66,26.66,26.66$ and $36.66 \%$ larval mortality respectively. Indeed, spinosad alone at 1.87 caused $40.0 \%$ larval mortality but caused $83.33,86.66$, 90.0 , and $86.66 \%$ larval mortality when this concentration was mixed with $\mathrm{BHA}$, EBI fungicides, difenoconazol, and penconazol or IGR flufenoxuron. Also, spinosad at $3.75 \mathrm{ppm}$ caused $46.66 \%$ larval mortality when was used alone, but caused 93.33, 90.0, 96.66 and $93.33 \%$ larval mortality when mixed with BHA as antioxidant, EBI fungicides and flufenoxuron as IGR respectively. Interestingly, the spinosad alone at $7.5 \mathrm{ppm}$ induced $73.33 \%$ larval mortality, this concentration caused $100 \%$ larval mortality when was mixed with BHA as antioxidant, EBI fungicides and flufenoxuron as IGR respectively. 


\section{2- Synergistic effect of Ergistrol Biosynshesis inhibiting Fungicides on chemical and natural insecticides on the $2^{\text {nd }}$ instar larvae of Spodoptera littoralis (Boisd)}

Results in Table (2) show the, toxicity and synergistic action of the tested compound used alone or in mixtures with EBI fungicides BHA or IGR at different concentrations to the $2^{\text {nd }}$ instars larvae of Spodoptera littoralis. The present data show that $\mathrm{LC}_{50}$ values of profenofos, esvenvalirate, spinosad and flufenoxuron were 1.90, 1.58, 1.44 and 1.83 ppm when used alone respectively. Were as the $\mathrm{LC}_{50}$ values, were decreased when these compounds were mixed with EBI fungicides $\mathrm{BHA}$ or IGR. The $\mathrm{LC}_{50}$ values were $0.08,0.20,0.24$, and $0.22 \mathrm{ppm}$ when profenofos was combined with $\mathrm{BHA}$, difenoconazol, peconazole as EBI and flufenoxuron respectively. These indicate that insecticidal action increased by $23.75,9.5,7.91$, and 8.63 folds respectively. Also these values decreased when esvenvalirate was mixed with BHA, EBI, and IGR. These values were $0.32,0.21$, 0.28 and $0.33 \mathrm{ppm}$ respectively, compared with $1.58 \mathrm{ppm}$ when esvenvalirate was used alone. The insecticidal action increased by $4.93,7.52,5.64$ and 4.78 folds respectively. In addition data indicated that the $\mathrm{LC}_{50}$ values were decreased when the spinosad was mixed with BHA, EBI or IGR while these values were $0.21,0.21$, 0.25 , and $0.20 \mathrm{ppm}$. When spinosad mixed with BHA, difenoconazol, peconazol, flufenoxuron respectively, compared with $1.44 \mathrm{ppm}$ for spinosad alone. The insecticidal action increased by $6.85,6.85,5.76$, and 7.2 folds respectively. These values were decreased when flufenoxuron was combined with BHA, EBI, however these values were $0.12,0.19$ and $0.22 \mathrm{ppm}$ when mixed with BHA, difenoconazol, penconazol, respectively, compared with $1.83 \mathrm{ppm}$ when this compound was used alone. The toxicity of this compound increased by 15.25 , 9.63 and 8.31 folds respectively. Mixtures of butylated-hydroxyanisol, difenoconazol, peconazol or flufenoxuron with different concentrations of organophosphorus insecticides (profenofos) or pyrethroids insecticides (esvenvalirate) or (spinosad) enhanced the toxicity of these insecticides. Interestingly, the $\mathrm{BH}$ as antioxidant, fungicides at different concentrations did not cause larval mortality

These results were also reported by (Schmuck et al., 2003) and (Pilling et al., 1995). They found that the EBI fungicides did not have toxic effect to honey bee. It is known that these fungicides inhibit cytochrom P450 monooxygenase system which prevents the biosynthesis ergosterol in fungi. Since, monooxygenase are also involved in the metabolism of organophosphorus, and pyrethroid insecticides (Littele et al., 1989 and Johnston et al 1989).Thus fungicides may delay the 
toxification, of insecticides by inhibiting monooxygenase system in the insects, and enhanced their toxic action against larvae. Moreover, it has been reported that fungicides that did not inhibit the biosynthesis of ergosterol in fungi did not enhance the toxicity of thiacloprid to honey bee (Schmuck et al.,2003). These results also, agree with the previous studies (Colin and Belzunnces 1992). They reported that the fungicides have been identified as synergists of pyrethroids insecticides in the honey bee. (Plling and Jepson 1994). Found that the toxicity of pyrethroid were enhanced from 9-16 folds when combined with EBI fungicides Prochloraz and Propiconazol to honey bee. The insect growth regulators ar acting as chitin synthesis inhibitor in insects which confers a remarkable specification with low toxicity to mammals, birds and fish (Flint and Smith 1977). Also, the mixtures between these compounds (IGRs) and traditional insecticides increase the efficiency of these insecticides (Abdel-Sattar, 1988). Also, (Raslan 2003) found that all mixtures of $25 \mathrm{ml}$ Spinosad with Consult, Atabron and Dursban at their half- recommended rates per feddan resulted in increasing their activity against the $3^{\text {rd }}$ instars larvae of cotton leaf worm. Also, (Helalia et al. 2006) found that the toxicity of the biocides was greatly enhanced when using low rates of conventional insecticides such as pyrethroids and some organophosphorus compounds in combination with $B$. thuringiensis proved to be suitable to control the cotton leaf worm S. littoralis Abd-EL-Mageed et al (2006) reported that spinosad gave moderately initial and residual effect when tested alone whereas the most pronounced initial effect was achieved when spinosad was mixed with methoxyfenozide. Also, they reported that the highest residual activity was noticed when spinosad was mixed with chlorpyrifos. Arakawa (2008) found that Polyoxin AL a fungicide that inhibits chitin synthesis, showed a synergistic effect with benzoylphenylurea insect growth regulators in killing Spodoptera litura larvae. The antioxidant butylated hydroxyanisol (BHA) which is a food grade chemical, enhanced the activety of fungicides thiabendazol and imazalil against Colletotrichum musae, the caused fungal pathogen of banana anthracnose (Kan et al., 2001) Additionally Mahmoud and Khalifa (2005) found that BHA increased the herbicide activity of the herbicide bensulfuron-methyl against radish especially with low concentration of the herbicides.

As mentioned before it could be used as mixtures of these BHA, EBI fungicides or IGR with the insecticides to in increese insecticidal activity at low concentrations. 
Table 1. Toxicity of chemical, natural insecticides and their mixtures on the second instar larvae of S.littralis .

\begin{tabular}{|c|c|c|c|c|c|c|c|}
\hline Treatments & & & \multicolumn{3}{|c|}{$\%$ corrected larval mortality } & & \\
\hline \multicolumn{8}{|c|}{ Profenofos } \\
\hline Concentration ppm & 0.10 & 0.20 & 0.40 & 0.81 & 1.62 & 3.25 & 6.5 \\
\hline Profenophos & 20.0 & 26.66 & 36.66 & 40.0 & 43.33 & 46.66 & 73.33 \\
\hline Profenophos +BHA & 46.66 & 73.33 & 83.33 & 86.66 & 90.0 & 96.66 & 100.0 \\
\hline Profenophos+flufenxuron & 44.82 & 66.66 & 73.33 & 86.66 & 93.33 & 96.66 & 100.0 \\
\hline Profenophos+difenoconazol & 46.66 & 66.66 & 70.0 & 86.66 & 90.0 & 96.66 & 100.0 \\
\hline Profenophos+penconazole & 43.33 & 66.66 & 73.33 & 83.33 & 90.0 & 96.66 & 100.0 \\
\hline \multicolumn{8}{|c|}{ ES-fenvalirate } \\
\hline Concentration ppm & 0.078 & 0.156 & 0.312 & 0.62 & 1.25 & 2.5 & 5 \\
\hline ES-fenvalirate & 24.13 & 27.58 & 37.93 & 41.37 & 44.82 & 48.27 & 75.8 \\
\hline ES-fenvalirate+BHA & 28.7 & 41.37 & 58.62 & 68.96 & 79.31 & 96.55 & 100.0 \\
\hline ES-fenvalirate+flufenxuron & 31.03 & 41.37 & 55.17 & 68.96 & 82.75 & 89.65 & 100.0 \\
\hline ES-fenvalirate+difenoconazol & 36.66 & 46.66 & 56.66 & 86.66 & 90.0 & 93.3 & 100.0 \\
\hline ES-fenvalirate+penconazole & 27.58 & 41.37 & 62.06 & 79.31 & 93.10 & 96.55 & 100.0 \\
\hline \multicolumn{8}{|c|}{ Flufenoxuron } \\
\hline Concentration ppm & 0.078 & 0.156 & 0.312 & 0.62 & 1.25 & 2.5 & 5 \\
\hline Flufenoxuron & 13.33 & 20.0 & 23.33 & 33.33 & 36.66 & 46.66 & 76.66 \\
\hline Flufenoxuron+BHA & 40.0 & 46.66 & 73.33 & 83.33 & 90.0 & 93.33 & 100.0 \\
\hline Flufenoxuron+difenoconazol & 26.66 & 46.66 & 63.33 & 73.33 & 83.33 & 93.33 & 100.0 \\
\hline Flufenoxuron+ penconazole & 24.13 & 41.37 & 62.06 & 72.41 & 86.20 & 93.10 & 100.0 \\
\hline \multicolumn{8}{|c|}{ Spinosad } \\
\hline Concentration ppm & 0.11 & 0.23 & 0.46 & 0.93 & 1.87 & 3.75 & 7.5 \\
\hline Spinosad & 13.33 & 20.0 & 26.66 & 33.33 & 40.0 & 46.66 & 73.3 \\
\hline Spinosad+BHA & 36.66 & 46.66 & 63.33 & 76.66 & 83.33 & 93.33 & 100.0 \\
\hline Spinosad+difenoconazol & 26.66 & 56.66 & 66.66 & 70.0 & 86.66 & 90.0 & 100.0 \\
\hline Spinosad+Penconazol & 26.66 & 43.33 & 56.66 & 83.33 & 90.0 & 96.66 & 100.0 \\
\hline Spinosad+flufenoxuron & 36.66 & 46.66 & 66.66 & 76.66 & 86.66 & 93.33 & 100.0 \\
\hline
\end{tabular}

$\mathrm{BHA}=$ butylated hydroxyl anisol

$\mathrm{EBI}=$ Ergistrol Biosynthesis Inhibiting fungicides 
Table 2. Synergistic effect of Ergistrol Biosynthesis inhibiting fungicides on chemical and natural insecticides on the $2^{\text {nd }}$ instars larvae of Spodoptera littoralis

\begin{tabular}{|c|c|c|c|}
\hline Treatments & LC50 & Slope & Synergistic ratio \\
\hline \multicolumn{4}{|c|}{ Profenofos } \\
\hline Profenofos & 1.90 & 0.65 & - \\
\hline Profenofos +BHA & 0.08 & 1.13 & 23.75 \\
\hline Profenofos + difenoconazol & 0.20 & 1.16 & 9.5 \\
\hline Profenofos + penconazol & 0.24 & 1.23 & 7.91 \\
\hline Profenofos +flufenoxuron & 0.22 & 1.25 & 8.63 \\
\hline \multicolumn{4}{|c|}{ ES-fenvalirate } \\
\hline ES-fenvalirate & 1.58 & 0.61 & - \\
\hline ES-fenvalirate +BHA & 0.32 & 1.26 & 4.93 \\
\hline ES-fenvalirate +difenoconazol & 0.21 & 1.16 & 7.52 \\
\hline ES-fenvalirate + penconazol & 0.28 & 1.66 & 5.64 \\
\hline ES-fenvalirate +flufenoxuron & 0.33 & 1.16 & 4.78 \\
\hline \multicolumn{4}{|c|}{ Spinosad } \\
\hline Spinosad & 1.44 & 0.77 & - \\
\hline Spinosad+BHA & 0.21 & 1.18 & 6.85 \\
\hline Spinosad+ difenoconazol & 0.21 & 1.18 & 6.85 \\
\hline Spinosad + penconazol & 0.25 & 1.64 & 5.76 \\
\hline Spinosad +flufenoxuron & 0.20 & 1.23 & 7.2 \\
\hline \multicolumn{4}{|c|}{ Flufenoxuron } \\
\hline Flufenoxuron & 1.83 & 0.88 & - \\
\hline Flufenoxuron +BHA & 0.12 & 1.05 & 15.25 \\
\hline Flufenoxuron +difenoconazol & 0.19 & 1.32 & 9.63 \\
\hline Flufenoxuron +penconazol & 0.22 & 1.39 & 8.31 \\
\hline
\end{tabular}

$\mathrm{BHA}=$ butylated hydroxyl anisol

$\mathrm{EBI}=$ Ergistrol Biosynthesis Inhibiting fungicides 


\section{REFERENSES}

1. Abbot, W.S. 1925. A methods for computing the effectiveness of insecticides. J.Econ.Entomol., 18:256-257.

2. Abd El-Mageed, M.E.A., M. E. Anwar, A.R.L Elgohary and H.F. Dahi. 2006. Field efficiency of novel biocide Spinosad singular, mixed with different groups of insecticides and compared with other biocide in sequence experiment on cotton leaf worm Spodoptera littorals. Bull.Ent. Soc. Egypt Ser(32) 91-99

3. Abdel- Sattar, M. M and A. El-Guindy. 1988. Effect the juvenoid tripene on the biological activity of the pink bollworm P.gossypilla (saund.) Agric.Res. Rev., 66:1 19-23

4. Amin, A. A and M. F. Gergis. 2006. Integrated management strategies for control of cotton key pests in middle Egypt. Agron. Res 4 121- 128.

5. Arakawa Toru. 2008. Synergistic effect of a fungicide containing polyoxin B with insect growth regulators (IGRs) in the killing of common cutworm Spodoptera litura (Lepidoptera: Noctuidae) Appl. Entomol. and Zool. Vol. 43, pp. 167- 171.

6. Colin, M.E., and L. Belzunces. 1992. Evidence of synergism between prochloraz and deltamethrin in Apis melifera Biological approach. Pestic. Sci $36: 115$

7. El-Dafrawy, M. E., A. Toppozada., N. Mansuora, and M. zeid. 1964. Toxicological studies on the Egyptain cotton leaf worm, prodenia dittorab $\mathrm{L}$. susceptibility of different larval instar of prodenia. J. Econ. Entomol. 57: 591593

8. EL- Nagar, A. 1998. Evaluation of certain foliar and micro- elements in an Integrated Pest Management (IPM) Program to control cotton boll worms. Msc.thesis. Fac. Of Agric. (Saba Bacha, Alexandria. Univ.Egypt. 176 pp.

9. Flint, H.M and R.L.Smith. 1977. Laboratory evaluation of TH 6o- 40 against the pink bollworm. J.Econ. Entomol., 70:51-53

10. Finney, D.J. 1971. Probit Analysis ( $2^{\text {nd }} E D$.) CombridgeUniversity Press Landon Pakistan. Agric. Pesticides. Association Bulletin $616-17$

11. Haque, H. 1991. Imported generic pesticides need to checked before marketing. Pakistan. Agric. Pesticides. Assoc. Bull $616-17$

12. Helalia, A. R., S.A, Abou-Donia., O.K. Mustafa. N. S. Abdel-Hai. 2006. Effect of certain insecticides in enhancing the potency of Bacillus thuringinsis against thecotton leaf worm Spodoptera littoralis. Ann. Agric.. Sci. Cairo. 51: (2) $573-5$ 
13. Hussein, N.M., F.F shalaby., E.F,EL-Khayat., S.M, Tawfik., M.S,Salem. 2002. Effect of certain organ chemicals on cotton growth and bollworms infestation during three successive seasons at kalubia governorate. Egypt. $2^{\text {nd }}$ Intern. Conf. Plant.Protec.. Res. Institute,Agric. Res. . Center, Cairo. Egypt 21-24 December, pp854-858

14. Johnston,G., G. Collet., C. Walker., I. Dawson., and D. Osbom. 1989. Enhancement of Malathion toxicity to the hybrid red legged partridge following exposure to Prochloraz Pestic. Biochem.Physiol.35:107-11

15. Kan,S.H., ked, J. and Magan, N. 2001. Control of the anthrancnose pathogen of banana Colletotrichum musae) using antioxidants alone and in combination with thiabendazole or imazalil. Plant Pathol., 50: 601- 608.

16. Littele, J., A.R. McCaughey., C.H. Walker, and T. Parker. 1989. Evidence for enhanced metabolism of $\mathrm{C}$ ypermethrin by a monooxygenase in pyrethroids resistant strain of the tubaco budworm (Heliothis veresens) Pest. Biochem. Bhysiol.34:58-68

17. Mahmoud, M.B and Kalifa,H.M.S. 2005. Enhancing the herbicide activity of bensulfuron methyl gainst radish by antioxidant Egyptian. J. Biotecnol,19: 300- 312

18. Pilling, E.D., and P.C. Jepson. 1994. Synergism between EBI fungicides and a pyrethroids fungicide and pyrethroids insecticides in the honey bee (Aphis melifera Pestic .Sci.39:294-297

19. Pilling, E.D., K.A Bromly-challenor., C. Walker., and P.C. Jepson. 1995. Mechanism of synergism between the pyrethroid insecticides lambadacyalothrin and imidazol Fungicides prochloraz. Pestic.Biochem.Physiol 51: $1-11$

20. Ragsdale, N.N. and H.D. Sisler. 1991. Mode of action of fungicide in Chemistry, Biochem and Toxicol of Pestic Education Program Organ State University P41-45

21. Raslan,A.A.S. 2003. Comparison of natural product Spinosad with some recommended Insecticides for the control of the cotton leaf worm at sharkia governorate Egypt. Egypt J. Appl.Sci 18 (4B)

22. Schumuck, R., T. Stadler and H.W. Schmidt. 2003. Field relevance of a synergistic effect observed in the laboratory between EBI fungicides and chloronicotinyle Insecticide in the honeybee (Aphis melifera). Pestic. Manag. Sci. 59: 279

23. Sun, Y.P and E.R. Johnson. 1960. Analysis of joint action of insecticides against house flies. J.Econ. Entomol., 53: 87-92 


\section{السمية والفعل التنشيطي بين بيوتيلايتيذ هيدروكسى انيسول والمبيدات الفطرية المثبطة لتخليق الايرجسترول في الفطريات و بعض المبيدات الحشرية ضد برئي ليرقات العمر الثانى لاودة ورق القطن \\ حسن فؤاد محمد عبد الحميد

$$
\text { معهُ بحوث وقاية النباتات- مركزالبحوث الزراعية - الدقي }
$$

تمت هذة الدراسة تحت الظروف المعطية بتغذية برقات العمر الثانى لدودة ورق القطن

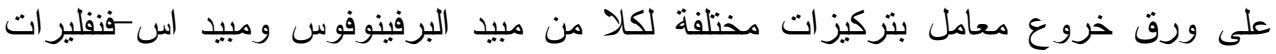
ومركب الفيلوفينوكسيرون وكذلك مركب الاسبينوساد حيث استعملت هذة المركبات إما منفردة أو في مخاليط مع بيوتيلايتيد هيدروكسى انيسول وبعض المبيدات الفطرية المثبطة لتخليق

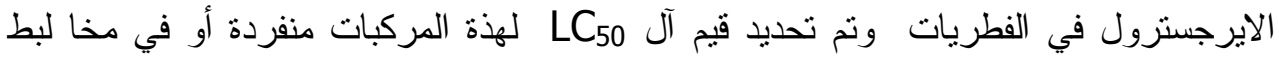

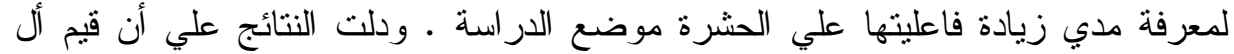

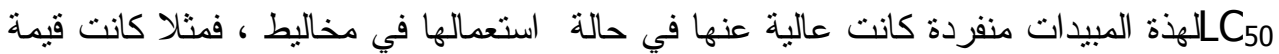

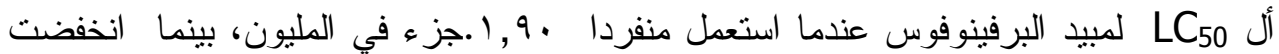

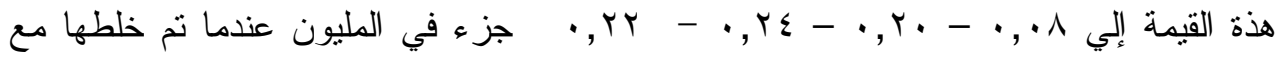
بيوتيلايتيد هيدروكسى انيسول من مضدات الاكسدة و الدايفينوكونازول و البنكونازول من

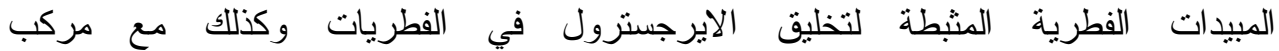

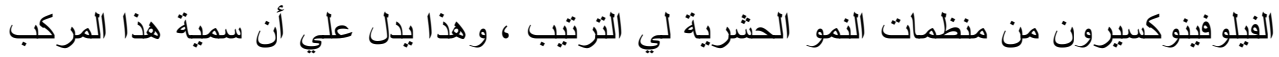

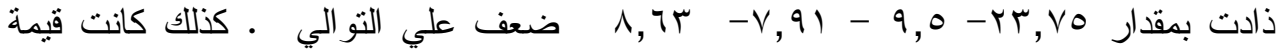

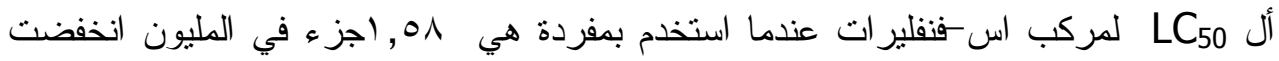

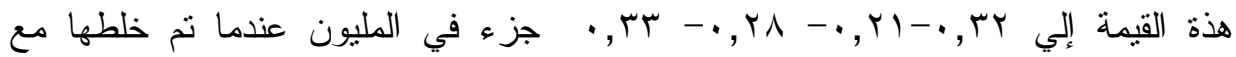
بيوتيلايتيد هيدروكسى انيسول و الدايفينوكونازول و البنكونازول وكذللك مع مركب

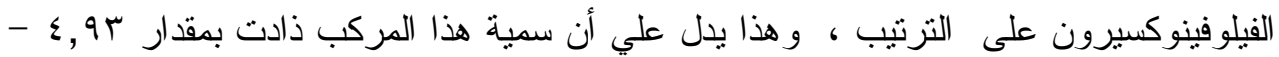

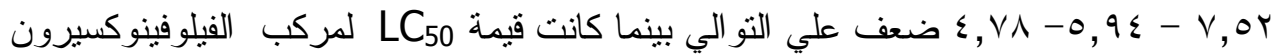

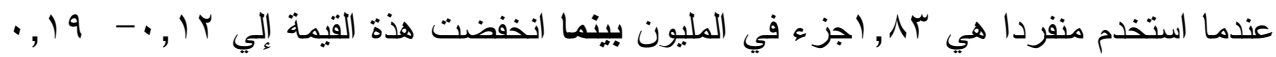

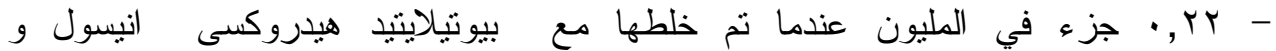

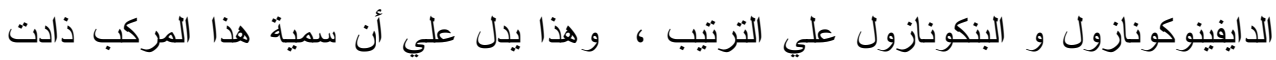

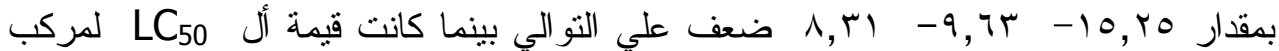

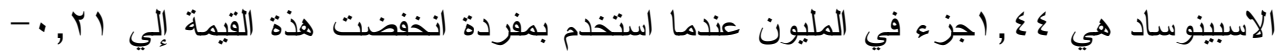

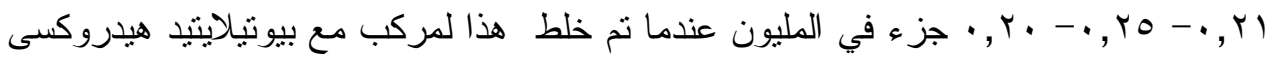

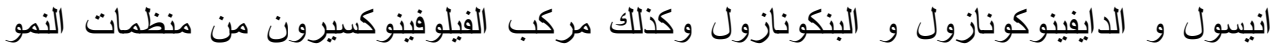

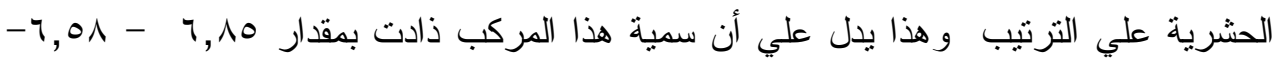

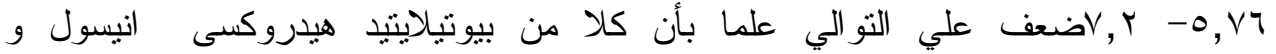

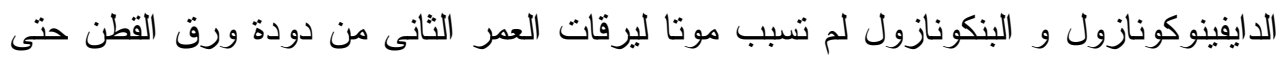

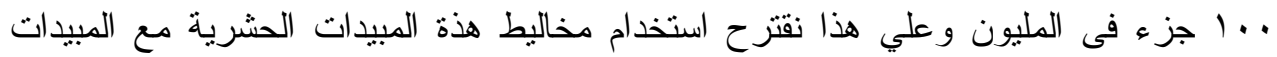

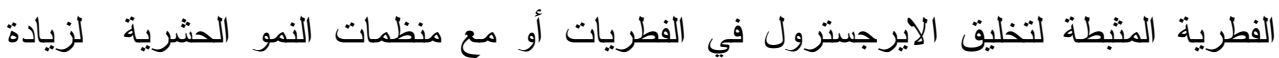
فاعلية هذة المبيدات علي يرقات العمر الثانى لدودة ورق الفئرئ القطن مما يؤدي إلي تقليل معدل 